\title{
Den atlantiske metafor
}

\section{Om Henrik Bjelkes „Time out“}

\section{Jens Peter Lund Nielsen}

Metaforen hos Bjelke er oceanisk af natur, ikke en bjergbo som Roman Jakobson kaldte den i modsætning til den metonymiske slettevandrer. Den metaforiske drift går mod det flydende, og hvor findes alle forskelles ophævelse, hvis ikke netop ved havet $i$ "Time out"? Der vil jeg-metaforen ubetinget hen og slutter $i$ Nattens Budapest og andre topografier derfor alt sammen i en atlantisk forsvarspagt imod metonymiens rejselyst. Metonymien der, til forskel fra det metaforiske jeg, ikke frygter objektmængdens forgodtbefindende, men tværtimod skylder det nærliggendes rækkefølge sit retoriske liv, synes derimod altid at have været draget mod det der mere end noget andet repræsenterer det naboagtige andet og derfor fylder metaforen med den største rædsel, ja: hotellet.

For Bjelkes fortæller, intet frygteligere end metaforens angstfyldte hotel i "Nattens Budapest"; dette er selve kønnets mareridtsagtige figur, søvnens diktat til hotelgæsten: elsk! At "Nattens Budapest" slutter, hvor "Time out" begynder: ved et pludseligt skift fra hotellet til havet, betyder dog ikke, at det metaforiske er blevet rejsende. Der er ved komplementaritet mellem havet og hotellet etableret metaforisk lighed gennem modsætninger, og derfor: trods "landkortet", ingen forcerede overgange i driftstopografien. Alle bevægelser finder kun sted inden for substitueringens vertikalitet; det hele er underlagt lighedsprincippet gennem jegets projektioner. Derfor også slutningen med den oceaniske suverænitet for første person præsens, som meta- 
forens foretrukne tid for at tale med Roman Jakobson. Tredie persons slettevandringer i prosaisk præterium tilhører alle fortiden, for ikke at tale om afstikkere fra lighedens strengt udstukne retning og derfor, under det metonymiskes fortrængning, metaforens ultimative fordring: glem Proust.

Af det oceaniskeskabte metonymien helst faste former. Vi husker som sådant Balbec-hotellet hos Proust, der som følge af nærhedsforbindelsen til Atlanterhavet forvandlede sig til et "akvarium". Metonymisk skilte det sig hensynsløst ud fra den oprindelige helhed, som havet metaforisk repræsenterede, ja metonymien syntes virkelig, ved sin troløshed over for altings oprindelsesfigur at være indbegrebet af et ondskabens hotel. Det store badehotel henviste ikke kun til eksproprieringen af moderhavet ved de mange; også korridorens forcerede accept af det naboagtige andet eller, med andre ord: selve bygningens prostituerende socialitet, kunne ikke være mere forræderisk over for den oceaniske metafors ødipale drift. Af badehotellet havde Proust således i forhold til havet skabt en virkelig transgressiv figur, metonymisk som selve erotikkens væsen.

Som om Bjelkes fortæller var en glemsom læser af Proust, blokerer metaforens mareridtsagtige immobilisering $\mathrm{i}$ ", angstens hotel" for selve narrativitetens metonymiske bevægelser. Flugten fra hotellet i „Nattens Budapest" er også afskeden med det fortælleriske; hvordan vil mødet med havet blive fortalt? På en måde har Bjelke i et essay om skriftens genetik givet sin fortæller grund til at forvente den symbiotiske ekstase. Ingen har mere trofast end fortælleren tjent den metaforiske substituering af driften mod livets tilbagevenden til sit udgangspunkt og derfor utålmodigt, og på en måde distræt, fortalt de historier, der nu engang er nødvendige for at komme til den egentlige pointe i form af skriveaktens maskeløse ejakulation.

Af masturbationens poetik skaber Bjelke en revanche for alle metaforens ydmygelser hos Proust. I modsætning til Proust, der bruger Madeleinekagens ødipale symbolik som lokkemad for 
den ufrivillige narrativitet og på den måde altid efterlader metaforen frustreret tilbage på metonymiens slettevandring, synes Bjelke virkelig at ville imødekomme metaforens store behov for aldrig svigtende forsyninger. I overensstemmelse med "Kærlighedens krop", hvor Norman O. Brown taler om symbolisering som oral inkorporering af objektet, tænker Bjelke derfor også den rene skrivedrift som en masturbatorisk indløsning af den symbiotiske selvforsyning. Hos Bjelke synes metaforen derfor aldrig mere at skulle lide det samme nederlag som hos Proust, der i Contre Sainte-Beuve erindrede sig masturbationens førstegangshandling som en metonymiens synekdokiske triumf, hvor vinduets suggestive syrengren svigtede inderlighedens falliske lighed til fordel for en pars pro toto-repræsentation af hele det eksteriøre landskab, der grænseløst udstraktikke fandt anden afslutning end billedet af guvernanterne, der med en skjult, men grusom reference til den atter frustrerede metafor, kastede et blik på deres ur som for at sige, at det endnu ikke var tiden for et mellemmåltid.

Til forskel fra guvernanterne synes Bjelke over for metaforen at spille moderens gode rolle, og som symbol for skrivedriften vælger han derfor fra den engelske tekst til et græsk vasemotiv billedet af ", a hairy satyre masturbating while pushing a penissubstitute in his own anus". På baggrund af metaforens historiske hunger virker intet mere forjættende end netop den selvavlende satyr; altid henvist til det torlagte ", andet" loves der med denne symbolske modermave metaforen tilfredsstillelse i det "sammes" flydende figur. Herfra er det metonymiske endeligt forvist; metaforen står foran muligheden for den enerepræsentation, der for allerførste gang vil gøre det muligt at inkorporere verden og forvandle universet til den urscenens androgyne figur, som een gang for alle vil ophæve alle forskelle og åbne for den endelige forløsning i tilbagevenden til det førerotiske "uterine“, hvorfra metaforen som ved en fejltagelse engang blev udstødt.

Uden på nogen måde at lade sig distrahere af Freud har Bjelke i sin skriftens genetik ført metaforen derhen, hvor den ville. Be- 
friet for alle Ødipuskompleksets gamle europæiske neuroser har den lighedssøgende sammenligning fået lov til at følge sit hjerte; „driftstopografisk" er den emanciperede metafor på rejse mod narcissismens urdyb, og besat af en altfortærende lyst til alle smertelige grænsers ophævelse og ved udsigten til at blive sin egen almægtige uterus, ender metaforen i „Time out” da også ved havet. Da livmoderen blot er, som Norman O. Brown siger, et introjiceret, inkarneret ocean, vil heller intet andet end foreningen med det sunkne Atlantis som sidste symbol på alle adskillelsers ophævelse være mætningspunktet for metaforen, og dette ville så have været fortællingens død, hvis ikke "Time out" var faldet anderledes ud.

Allerede historiens indledning markerer den for alle uventede afbøjning af metaforens frie fald mod det arkaiske moderdyb. Alene med fortælleren ved havet standses brat metaforens ekstatiske bevægelse mod den symbiotiske forening; nærmere målet end nogensinde ser den oceaniske metafor sin sejr over metonymien forvandlet til et nederlag, og opdager for sent at fortælleren ved synet til havet bryder hele pagten med den atlantiske poetik og ved et omslag i stilen blokerer for den ejakulatoriske forening med det tabte element. Sammenligningen der gik efter ligheder og på alle måder stillede sig i det oceaniskes tjeneste, synes ved vejs ende afvist af en krop, der konfronteret med selve havet, pludselig kender forskel og ikke mere lader sig bedrage af billeder. Så nær ved havet virker selv metaforen for ernæringsfattig, og straffes for sin pergamentagtige natur. Alle benægtelser til trods tilhører metaforen også billedkategorien og skjuler under lighedens maske ikke færre uforeneligheder med genstanden end syndefaldets gamle figenblad.

Under havets tavse blik gik det altså anderledes end forventet. Allerede de indledende sætninger i „Time out” nægter metaforen foreningen med det flydende. På sporet af den tabte enhed skulle den alligevel ikke finde fiskens lykke i det grå fluidum af sæd og mælk, som det blev lovet i billedet af den másturberende satyr; nej, metaforens sejr blev faktisk dens fald. Så nær det store 
symbol for oprindelig ernæring bliver metaforen efterladt som en drømmerest fra køkkenet, en lille stivnet figur ved historiens begyndelse: en sovseskål med form af et skib, en flaske sat i bunden af skålen ligesom en mast. Altså kun en skål og ingen næringssubstans; blev metaforens løn en udtørring? Som en beruset båd går hele figurens drift mod havet, alle osmotiske forbindelser med det grænseløse element bliver dog nægtet den. For flydende indhold er flàsken også tømt, den er i øvrigt tilproppet: hvad blev der af den stærkt begærede ejakulation? Alt metaforisk begær som det blev udtrykt i satyrbilledet, stivner livløst her i en straffende parodi på den androgyne almagt. Stilen $i$ "Time out" vil slet ikke kendes ved metaforen, den henviste til den tilstand af absolut præsens, hvor den selv skulle blive overflødiggjort, og eksisterer ved tærsklen til evigheden kun som en fortidsrest, et fornægtet drømmmeelement, snart fuldstændig glemt, ligesom de sætninger af Baudrillard, som fortælleren læser uden bagefter at kunne huske et ord.

At glemme Baudrillard. Ja, fortælleren taler om Amerika som om sætningerne kun kunne været skrevet i det øjeblik, hvor de ikke længere har nogen betydning. "Time out" er med andre ord hinsides Amerika, alle fantasier er her tilbagelagt på en sådan måde, at "Time out" faktisk bliver en mere virkeliggjort utopi end Baudrillards. Derfor virker også tilstedeværelsen af "turisterne" i "Time out" mere end anakronistisk; disse synes endnu fanget $i$ utopiens spor, fordi de længes efter "solskinssituationen". Som det gælder for Baudrillards "europæere“, er ",turisterne “ i "Time out" altfor mærket af fortidens revolutionstænkning; de forestiller sig vejret anderledes og accepterer dermed ikke den tidløshed, som havet så fuldstændigt synes at figurere, at det for fortælleren repræsenterer selve den konstans, som er det samme som evigheden, fordi det aldrig forandrer sig. Synet af havet forleder ikke fortælleren til at tænke på noget andet; vandet er for ham hinsides alle stilfigurer og repræsenteres derfor som en stilens spændingsløshed hinsides Baudrillards retoriske rodeo, som metaforiserer svimmelheden på randen af den død, der så blødtfigureres af „Amerika“. „Time out“ synes virkelig nærmere 
de flydende identiteters paradis end Baudrillard; over for maskens snarlige forsvinden må fortælleren da også overgive alle stilens frenetiske spasmer til glemslen og lade Baudrillard dele skæbne med flasken og sovseskålen.

Fortælleren selv er et andet sted, nærmere forsvindingspunktet end metaforen han har lagt bag sig, og glemt. Han insisterer på en position hinsides billedet, altimens skriveviljen resterer som en magtmanifestation, der i samme grad som afmagten melder sig over for de figurer, der spærrer for fortællerens adgang til havet, forvandler sproget til en tikkende bombe. Frustreret i forhold til forjættelsen om den rene skrivnings symbiose bemægtiger et voksende had sig fortælleren i samme grad det ikke lykkes at udrense landskabet for utopiens "turister". Over for disse virker fortælleren som et sprænghoved og glemmer et øjeblik sprogets billedløse stil til fordel for en metaforisk endlösung: "turisterne" virker som "lus og lopper" på fortællerkroppen. At "Time out" så alligevel ikke udrenser det parasitære "andet", men i sidste instans bøjer af for dets tilstedeværelse, og ikke lader det hele eksplodere i en havstokkens American Psycho bliver nu begyndelsen til en anden og ufrivilligt fortalt historie.

Frivillighedens historie kender vi; det er beretningen om det "samme" fortalt af et defensivt jeg. Stærkt behersket som en kroppens politiker og derfor afvisende overfor det, der ikke repræsenterer samme konstans som havet, synes fortælleren at have indgået en livskontrakt med netop dette element. At prisen for udstrækningen af den tid, som havet så tavst tilstår kroppen skulle være afkaldet på alle forbindelser med det ",andet“, synes hævet over enhver tvivl. Ingen kender betingelserne bedre end fortælleren, som derfor heller ikke på nogen måde indlader sig på de eventyr, der kunne vække havets dybe vrede og kalde hans krop tilbage som en forfalden veksel.

På den anden side: som virkninger af en lov som fortælleren ikke synes at være herre over, og som mest af alt virker som resultatet af en hemmelig drifts ubevidste tilskyndelser, kommer de „an- 
dre" tilsyne hver gang fortælleren ser på havet, og forstyrrer kroppens kontrakt med dette "samme“ som dette element tilsyneladende så trofast figurerer. Vi tror gerne, at fortælleren ikke på nogen måde frivilligt genkender "turisterne" som det libidinøses figuranter så udfordrende nær ved dødens flydende metafor. Fortælleren synes så opfyldt af sin kropsbevarende mission, at han ikke i drifternes historiske strid virker som den, der har modet til at spille dobbeltagentens rolle, han er virkelig ingen eventyrer; skulle han under dække af at have neutraliseret dødsdriftens oprørske rival, tage parti for kærlighedens subversive operationer på selve strandbredden? Alligevel står vi tilbage med brudstykker af et bedragerisk mønster, for i en forskydningsmæssig beskrivelse af historiens "turister" bemærker vi også en stilens underliggende distraktion over for udsættelsens strenge kontrakt. Netop fra havets nærhed låner "turisterne" deres farve, og som et retorisk syndefald fortæller deres grå udseende om det metonymiskes tilbagekomst, hvor det sidst af alt var ventet.

Ikke anderledes end rosenfloret af purunge piger hos Proust har "turisterne" i „Time out“ krydset fortællerens vej mod havet; vil han ligesom den omvendte Ødipus i På sporet efter den tabte tid også ufrivilligt efterspore det kvindelige bedrag som den fortælleriske modpol til den ødipale metafor, og i givet fald: hvor vil han så i dette helt åbne landskab finde en sådan kvinde? I det skjulte, og måske som en virkning af alt det fortælleren fortrænger i sin livsforlængende troskabskontrakt med havets tavshed, frister "turisterne" med metonymitet, men ethvert lovbrud synes fortælleren fremmed. For ham har havet altid været det tavse vidne, dertil førte metaforen ham også, og andre livsvilkår end den erosfjendtlige kontrakt med havet synes ikke mulige, hvis ikke metaforens atlantiske drift atterskal genoplives, så den med foryngede kræfter igen vil bringe alle spændinger til udladning for at kunne skyde genvej til livets dødelige mål.

Tilbage til havet! Trods forsikringerne om det modsatte vil fortælleren måske alligevel ikke havets tavse trofasthed? At havet 
kan figurere andet end dødens moderlige væsen forbyder fortælleren sig selv at erkende. Han fanger havet ind i vanens troskabskrav og efterlader det ingen muligheder for at undvige dualiteten. Som fangevogter af havet gribes fortælleren dog af søvnighed; hvem holder øje med havet om natten? Morgenens første blik på havet afslører da også stærkt begærede tegn på nætternes stormfulde eventyr, bølgernes „hvide skum“ er her suggestive udtryk for den ",anden " natur, som fortælleren kun sovende indrømmer havet. Vågen tror han sig i paradis, han er ingen lovbryder og vælger ikke frivilligt syndefaldet. Historiens fortsættelse afhænger endnu engang af metonymien, den viste sig narrativ virksom i forbindelse med gråfarvningen af "turisterne"; ligeså subversivt måtte imidlertid også naboskabet med livets veritable rejsende virke ind på havets væsen. De nære forbindelser med utopiens gamle nomader gav heller ikke havet noget valg: det måtte forestille sig et helt andet liv og havde som følge af alle oprørsfantasierne allerede længe før fortællerens tilbagekomst været på flugt fra oprindelsens fængslende figur for illegalt at blive det, som er det flydende allermest forbudt: en Albertine. 